\title{
Readiness of fashion education and training institutions management in facing the industrial revolution 4.0 and society $\mathbf{5 . 0}$
}

\author{
Miftahul Annisah Nurfitria (iD *, Widihastuti Widihastuti (D), Nur Kholifah (D), \\ Sayidatul Maslaha \\ Universitas Negeri Yogyakarta, Indonesia \\ * Corresponding Author. Email: miftaannisah@gmail.com
}

\section{ARTICLE INFO}

\section{Article History}

Received:

29 September 2021,

Revised:

15 October 2021;

Accepted:

30 November 2021;

Available online:

15 February 2022

Keywords

Industrial Revolution; Management;

Society 5.0

\begin{abstract}
This study aims to determine how the management of education and fashion training institutions is prepared to face the industrial revolution 4.0 and society 5.0. This research is a case study research by examining field conditions. The data collection method is triangulation with observation, interviews, and documentation. The data of this study were obtained from the head of the institution, instructors, and course students. Technique triangulation and source triangulation were carried out to check the validity of the data. The research was conducted at the Yogyakarta Career Busana course and training institute. The research results based on the principles of POAC (planning, organizing, actuating, controlling) include the condition of the institution's management such as the institution's program curriculum, institutional management, strategy, program implementation, and control strategies and techniques in management. The results show that a strategy is needed to increase the readiness of educational institutions and fashion training for industrial revolution 4.0 and society 5.0. The development strategy can be seen from several aspects of the management function, namely planning, organizing, activating, and controlling. Institutions that have good readiness for the industrial revolution 4.0 and society 5.0 have aspects of management functions that are by the development, needs, and conditions of the industrial revolution 4.0 and society 5.0.
\end{abstract}



This is an open access article under the CC-BY-SA license.

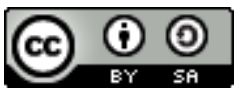

How to cite:

Nurfitria, M. A., Widihastuti, W., Kholifah, N., \& Maslaha, S. (2021). Transferable skills perception analysis of vocational high school teachers on-in-on-in dual skills program. Jurnal Pendidikan Vokasi, 11(3), 265274. https://doi.org/10.21831/jpv.v11i3.44094

\section{INTRODUCTION}

The sophistication of technology provides changes in all areas of life. Changes need to be made according to the times and needs. Increasing challenges and opportunities result in the development of management that must be carried out in stages, planned, and sustainable so that it can produce a quality and according to the concept of objectives, especially in the industrial world, which has significant dynamics of change from time to time. Revolution 4.0 and society 5.0 are a form of human change experienced in the 21 st century (Hermann et al., 2016). Various kinds of new technologies are present to simplify the system of life. Digitalization is becoming a megatrend and a force that is very influential on changes in human life around the world. On the other hand, digitalization is also a new problem for humans in the scope of competence, where humans must learn more to align their competencies according to this era. Technological innovations that are influential and highly developed in this era are autonomous vehicles, 3D printing, advanced robotics, and new materials (Schwab, 2016). Technology seems to be a necessity that humans cannot separate. 
The dependence will be increasingly felt because of the conveniences offered, and especially information will be very easy and cheap to access with the internet. The existence of technology that provides convenience and will slowly form an intelligent society, or an intelligent 5.0 era society in developing social and community problems by utilizing technology by adjusting the potential of the existing local community (Salgues, 2018). Not only for human individuals, problems due to digitalization occur, but also for educational and training providers. For educational and training institutions, digitalization is a big and complex problem because it has to make its graduates have standards in accordance with digital-based industries.

Industry requires competent and globally competitive human resources. For humans to be able to compete, programs organized by educational and training institutions must be truly adapted to conditions and needs. In addition, the demand for mastery of several skills on everyone must be met because of uncertainty, and changes in types of work in the industrial world will occur quickly. New jobs will appear replacing old jobs that are no longer relevant. This type of work in the 21st century will have a lot to do with digitization, the internet, smartphones, and laptops that can be done anywhere, anytime, and by anyone. Quick decision-making skills, communication skills, critical thinking skills, technology skills, and the ability to innovate will always be needed by industry in the 21 st century (Bell, 2010). In the end, vocational education and training are the keys to economic sustainability because they can produce competent human resources.

Educational and training institutions are a bridge between the world of education and the industrial world wherein these institutions there will be a vocational learning process. Education and training institutions are vocational education institutions that aim to increase the relevance of the world of education and vocational training by labor developments. The processes and systems in this vocational institution must be arranged in an actual and contextual manner based on the current conditions (Sudira, 2018). These vocational education institutions can be organized through formal education such as vocational schools or non-formal education such as job training centers or course and training institutions.

Increasing competence through the learning process must be considered and carried out. Humans have to learn a lot and practice anywhere, anytime, and with anyone to improve competence. The process and experience of learning and training can be obtained in formal and non-formal institutions. Skills are the key to productivity and modern economic growth, both macro and micro. These skills are also a reference and measure of the competency level of human resources (Mcgrath $\&$ Mulder, 2019). Lessons and training are an inseparable part of education. The success rate of an education and training program is supported by several things, including materials that are prepared according to needs objectives and can increase knowledge, methods used according to the type of program, the instructor's ability to deliver materials, facilities, and principles of learning, training participants and evaluation of training (Zainal et al., 2014). To realize the success of education and training programs, methods that are by the programs offered include the on-the-job training method and the off-the-job training method.

Vocational education is one of the educations that prepare students to become workers (Terry, 1977). One of the institutions that can provide vocational education is non-formal education. The provision of education can serve based on the objectives of the economic system, namely welfare, and the contemporary dynamics of society, such as based on the needs and problems that occur in society. The learning process is carried out in the form of social movements and learning environments through informal apprenticeships, while the institutional process is not too structured and is oriented towards the formal labor market and the non-formal labor market (Singh, 2005).

The number of training institutions in Indonesia in 2020 is 5,020 registered institutions of the Ministry of Manpower. However, the number of accredited training institutions is still very small, namely 1,622 institutions. The number of accredited institutions is almost half (Kementerian Ketenagakerjaan Republik Indonesia, 2019). Therefore, this research needs to be done to find out how far the management process is carried out and how the level of readiness of educational and training institutions to face the industrial revolution 4.0 and society 5.0. This is because of the importance of management for the development of an educational and training institution. Institutional managers can use this research as a reference in making decisions on the development of institutional programs. Many studies on institutional management have been carried out, but the 
research that shows the level of readiness of educational institutions and fashion training for the industrial revolution 4.0 and Society 5.0 has not been found.

\section{RESEARCH METHOD}

This study aims to determine the level of readiness of educational institutions and fashion training for the era of the industrial revolution 4.0 and Society 5.0. This research is descriptive qualitative research with a triangulation data collection method. The triangulation technique is a data collection technique with participatory observation, in-depth interviews, and documentation as the data source (Sugiyono, 2013). The data collection process is carried out at the career busana course and training institution. This institution was chosen because it provides a fashion training program. This institution has also been accredited by National Accreditation Board for Higher Education, Ministry of Education and Culture of the Republic of Indonesia and has several achievements, both from the achievements of managers or instructors and the achievements of the course students.

The analytical technique used in this research is the descriptive analysis technique. Data analysis in the study was carried out during data collection and after (Miles \& Huberman, 2009). This study's data analysis was based on data from interviews, observations, and documentation at the career busana course and training institution. The subjects who were the sources of data in the interviews in the research were the heads of institutions, instructors, and course students. Besides that, documents related to learning in the course and training institutions are also analyzed to strengthen research data.

\section{RESULT AND DISCUSSION}

Management of an institution is a process in regulating the institution to achieve specific targets. The cooperation process is an important factor that determines the level of achievement in an educational institution. Humans are the main element that influences how management occurs in addition to materials, markets, money, and methods. Management is defined into three things, namely management as a process, management as a collectivity, and management as a science or art. Management as a process is managed as an implementer in achieving certain goals. Management is a collection of people who work and gather to achieve a target is management as a collectivity. At the same time, management as a science or art is always related to the principles of management itself.

Achieving an organizational goal effectively and efficiently cannot be separated from the existence of management. In terms of management, effective is the goal that is achieved according to plan, while efficient means that the tasks given in the organization are carried out properly, well, organized, and completed according to the specified schedule (Terry, 1977). Management is a process consisting of action, planning, organizing, mobilizing, and controlling. The management process in an organization is carried out aiming to facilitate the organization so that it will be easy to achieve goals effectively and efficiently. In addition, management will also create harmony in work and a dynamic organization.

The management functions that are widely used consist of planning (planning), organizing (organizing), actuating, coordinating, and controlling (Wijaya \& Rifa'i, 2016). Another opinion suggests that the basic functions of management are planning, organizing, actuating, and controlling, which is abbreviated as POAC (Terry, 1977). Planning is carried out in the management process to get an overview of strategic steps to realize the most important organizational goals. The principle of planning or planning is carried out not only focusing on the vision and mission of the organization or institution but also planning to manage and use the resources owned by taking into account the limitations. Planning in an organization or institution must be made specific, measurable, achievable, realistic, and has a time limit so that it is easy to evaluate the program of the organization or institution.

The organizing principle is a specific and clear division of assignments to members of the organization or institution by the fields and abilities of the members. The division in this way is done so that the plans are made run systematically. Organizing activities can be divided by dividing work 
fields or commonly called departments or divisions. The division of tasks according to these competencies will determine the level of success of an organization or institution. The third principle is the actuating principle, which is the principle that underlies directive activities in the management of institutions or organizations. This briefing activity must be synergized with planning and organizing. The institutional management ability of a head or chairperson is needed in this process to instill a culture of discipline, totality, work smart, work together, and work hard. The last principle is that controlling this activity is usually carried out by evaluating, inspecting, auditing, supervising, and supervising the implementation of the work program that has been agreed upon. The benefit of this activity is that it can find out problems that occur early on so that it can be a guide in determining decisions on the institution or organization in carrying out development. In addition, it can also find out the extent of performance achievements.

Planning Strategy for Fashion Education and Training Institutions to Produce Graduates Who Have Competence According to the Era of the Industrial Revolution 4.0 and Society 5.0 (Planning)

Planning is the process of formulating a strategy to determine the goals to be achieved in an educational institution and fashion training. An organization requires cooperation between individuals involved in it to achieve common goals (Thach \& Murphy, 1995). Planning in an organization can include vision, mission, and ways to achieve goals. Careful planning will produce optimal output. Planning is seen as an effort to maximize the potential of an organization's resources, including human resources, finance, production tools, raw materials, technology, markets, and information. Therefore planning is fundamental to carrying out various activities to achieve a goal (Wijaya \& Rifa'i, 2016). The planning process must make adjustments to what is needed and will be carried out based on the involvement of the process of determining the desired future state compared to the current conditions so that the gap will be seen, and details of alternative selection in closing the gap of the situation which includes effectiveness and efficiency.

The planning process is carried out by compiling program planning through a curriculum that is adapted to the conditions of need in the era of industrial revolution 4.0 and society 5.0. The curriculum is an action plan on a written document that includes strategies for achieving goals. This curriculum also describes the form of learning experiences that students will get in the classroom and outside the classroom as long as it is written in the curriculum. Aspects that are loaded in this stage of curriculum preparation include objectives, the content of teaching materials, learning strategies, media used in learning, and evaluation of learning used.

Key skills in vocational learning in education and training institutions include the ability to solve problems creatively using critical thinking, the ability to build relationships with others, the ability to work together, the ability to use language, symbols, and text interactively and effectively in communicating both oral and written, the ability to access and analyze information into new knowledge, the ability to use internet-based communication and information technology, the ability to innovate, the ability to lead, assess, and make decisions, the ability to negotiate, the ability to provide satisfying customer service and the ability to continuously develop self must be mastered as a determinant of competence capability.

For learning to produce human resources who have these competencies, reforms in the management of educational and training institutions must be carried out. Curriculum planning must pay attention to the character of a good curriculum, namely by applying the principles of curriculum development. The curriculum of educational institutions is made relevant to the needs and learning conditions of the industrial revolution era 4.0 and society 5.0, such as applying appropriate learning methods and strategies so that work skills, work knowledge, work attitudes, and work morals are competitive and of high quality (Sudira, 2018).

The curriculum is developed based on the needs of students, developments in science and technology, community needs, and industrial needs. From the existence of these needs, the objectives of the curriculum are determined, determine the learning experience be obtained, organize appropriate learning experiences, and evaluate the learning process. The career busana course and training institution implement a curriculum based on Indonesian National Work Competency Standards Customade No. 90/MEN/V/2010 in collaboration with Indonesian National Work Competency Standards Customade garment 2020 No. 177 with digital learning methods. The 
Indonesian National Work Competency Standards Customade collaboration is applied to produce a curriculum that is by the conditions of the need for competence in the industrial revolution, competence according to the needs of the community, and competence according to the needs of the fashion industry in this era. Indonesian National Work Competency Standards Customade Customade No. 90/MEN/v/2010 has the advantage of many competencies provided and complex materials according to the needs of fashion in society. Indonesian National Work Competency Standards Customade Garment 2020 No. 177 is applied because it has the advantage of being able to meet competencies and skills according to the standards of the fashion industry in this era.

In addition to program planning, planning for all aspects of needs that also support processes in institutional performance is also carried out such as the number of human resource needs, the need for infrastructure that supports the learning process, program budget planning, to long-term planning in the form of strategies for developing educational and training institutions. The planning must be calculated carefully and based on the priority scale. It is also important to do in planning, namely a SWOT (Strength, Weakness, Opportunities, Threats) analysis so that the weaknesses of the work program that will be carried out will be known. Knowing these weaknesses can provide direction or instructions for managers to make decisions.

The career busana training educational institution carries out a careful planning process from the beginning to the end. The number of institutional resource needs, including the head of the institution, instructors, and admins, is six people consisting of one permanent instructor, three contract instructors, one permanent admin, and one contract admin. This amount of human resources is planned and adjusted to the needs of the fashion training and course institutions. Likewise, the facilities and infrastructure and the program budget are also adjusted to the number of course students in each study group.

The development strategy in the long-term plan also needs to be carried out. The development strategy in the long-term plan of the career busana course institution is by the vision and mission of the institution. Becoming a strong, environmentally friendly and character-based course and training institution is a long-term plan for this institution. While the institutional development strategy in the long-term plan is to produce graduates who believe and are devoted to God Almighty and have a noble character, are capable and ready to face global challenges, are entrepreneurial, creative, innovative so that they can create jobs, competent according to the needs of the market share. The workforce is knowledgeable and concerned about the environment and can actualize the capabilities possessed.

The Strategy of the Process of Managing Educational Institutions and Fashion Training in Regulating Work Mechanisms so that Goals can be Achieved Optimally (Organizing)

Organizing or the mechanism for the division of tasks within an institution or organization is very important to do so that program goals and organizational or institutional goals are easily and quickly achieved. Organizing is part of meeting various interests and utilizing the potential of human resources in the institution in a certain direction and purpose. Organizing is part of determining, grouping, and compiling various kinds of activities needed to achieve organizational goals. In organizing, the leader or head of the institution must place human resources or staff in positions that are by their competencies. Organizing must be done based on an understanding of organizational goals that must be understood by all staff, clear division of work, procedures for determining how to work, clear evaluation and punishment, a delegation of authority according to the duties and functions of each position and clarity of coordination lines in the institution (Terry, 1977).

The skills of the head of the institution in managing programs and work systems are very much needed to achieve common goals. A new strategy to manage a working system that is by the conditions of the industrial revolution 4.0 and society 5.0 is needed to support this process (Winanti et al., 2019). Especially in this era, digitalization is present and has an important influence on the changes that occur in all aspects of life. The communication process, coordination between institutional members, learning, and various other processes must transform and adapt to digital conditions. 
The strategy in regulating the working mechanism at the career busana course and training institution has been carried out, for example, the division of work assignments for instructors and admins. The work reporting process is carried out periodically together with evaluation activities. The process of reporting activities and documenting the evaluation of institutional activities is also carried out using a system that utilizes digital technology, such as websites and utilizing Google Drive. For staff who have good performance will get a reward.

During the evaluation process, a discussion of the next program development strategy for the institution was also carried out. Not only that, the coordination process related to the time or schedule of learning to the learning process is also carried out so that it is known how far the competencies absorbed by students are. There is also a collection of alumni data from graduates of course and training institutions to know to what extent output is absorbed in the industrial world.

\section{Strategy for Implementing Program Plans for Fashion Education and Training Institutions} (Actuating)

The program is a part of a plan that is systematically arranged. The program is a formulation that contains a description of the work to be carried out along with instructions on how to implement it (Syamsi et al., 1982). Work programs in institutions or organizations are made to realize the ideals contained in the vision and mission. The preparation process is carried out in a directed manner based on mutual agreement between the management or agency managers and considering various aspects such as community needs. The work program compiled will help make it easier to work so that its implementation is more regular. In addition, the work program can also function to answer the needs of the institution's organization as well as external demands.

The program is the first element for the creation of an activity that has aspects, namely the objectives of the activities to be achieved, the activities taken in achieving the goals, the rules that must be adhered to and the procedures to be followed, the estimated budget needed and the implementation strategy. It can be concluded that the program of action is based on a clear theory that determines the social problems that occur and want to be overcome. Before determining it, intervention and serious thinking can be carried out on the problem until the best solution is found. Therefore, it can be concluded that the determination of the program must be adjusted to the needs to achieve the objectives of the program implementer.

A program structure and plan for education and training institutions need to be a key in paving the way for its vision and mission. There are three activities in operating the program: the organization of a clear organizational structure, the interpretation of the implementers, must be able to run the program by technical instructions and implementing instructions. So that the expected goals can be achieved, the application needs to make clear work procedures so that the program can run according to the plan, including the schedule of activities, so that it does not clash with other programs (Meriza, 2018). Action is something to turn decisions into operational patterns in achieving big or small changes. At the same time, implementation refers to a person's actions in achieving the goals set based on a decision.

One of the implementation models is a model using a learning process approach called the program implementation suitability model. The implementation model has three elements: the program, program implementation, and program target groups. A program will be said to be successful if the three elements match. These elements are the suitability between the programs needed by the community and the programs offered by the institution or organization, the suitability between the program and the organization or institution, which includes the suitability of tasks with organizational capabilities, and the suitability between the beneficiary group and the program implementing organization which includes the conformity between the requirements decided by the organization to be able to obtain program output (Rizani, 2019).

Educational institutions and fashion training implement work programs, including course packages that have been adapted to the needs of the community. Problem analysis is also carried out in the process of determining the type of training course, as is the case in making a buffet system course package program that provides learning services according to the knowledge needs of students. Students can choose and decide what they want to learn to sew in this case. 
Internal Communication in Education and Training Institutions

Communication is one of the determinants of the quality of relationships within an institution or organization. The effectiveness of communication depends on the ability to understand one another (communication depends on our ability to understand one another). Along with the sophistication of technology, communication in institutions in era 4.0 and society 5.0 is mostly done online through Whatsapp groups. Communication in this way has the advantage of being easy to do anywhere, anytime (O'Hair et al., 2009). But on the other hand, there is also a weakness that online communication is considered less effective because in some cases, there is a lack of response from certain people, and in some cases, students underestimate passive learning in the learning process.

Career Fashion courses and training institutions utilize developing technology to carry out internal communication processes. WhatsApp is the most frequently used social media in addition to direct communication. The choice of this technology is considered more effective because it can be discussed in groups. In addition, internal communication that is carried out during discussions in discussing a matter is also often used in Zoom Meetings or Google Meet. Although this technology still does not provide an optimal communication process, it has greatly shaped the long-distance communication process.

Learning Models and Learning Methods According to the Industrial Revolution 4.0 and Society 5.0

The learning model is a systematic procedure or pattern that is used as a guide to achieving learning objectives in which there are strategies, techniques, methods, materials, media, and learning assessment tools. At the same time, the learning method is the method or stages used in the interaction between students and educators to achieve the learning objectives that have been set by the material and mechanism of the learning method (Afandi et al., 2013). The learning model is a method, method, or strategy in teaching and learning activities with four elements: syntax, the social system, the principle of reaction, and a support system.

The demands of digitalization in the world of education are increasingly changing traditions and ways of learning for everyone. This learning model, due to digitization, has different characteristics from the traditional learning of the past. The characteristics of the learning include a learner-centered learning approach, collaborative learning, contextual learning, and learning that involves social conditions. Learning is also more flexible, not bound by space and time, because access to information and knowledge is getting easier and cheaper.

The career busana course and training institution indirectly applies the project-based learning model. The learning process is carried out such as by exploring sewing techniques, designs, and fashion decoration through the internet. This exploration is carried out in the learning process to make various types of fashion. The project-based learning model is a learning model based on projects as the core of learning. In this learning model, students are required to explore, assess, interpret, and synthesize information to obtain various learning outcomes (knowledge, skills, and attitudes).

Strategy Controlling the Management of Educational Institutions and Fashion Training in Learning and Organizational Performance (Controlling)

Controlling is one of the management functions that the principal must carry out as a leader in the school. Supervision is the process of observing or monitoring the implementation of organizational activities to ensure that all work being carried out goes according to a predetermined plan. Thus, supervision is the last process of a series of other management functions (Meriza, 2018). Supervision in an organization or institution is intended to prevent errors from occurring. The supervisory function is closely related to the directing or commanding function in the organization of institutional activities. As one of the management functions, supervision is the last action taken by managers in an organization.

Directing also functions to evaluate the successful implementation of employees' duties and improve the efficiency and performance of educational institutions' activities. At the same time, directing develops a better work situation through coaching and professional improvement of 
employees and providing direct guidance to correct errors, shortcomings, and mistakes, as well as helping to solve problems faced by employees to prevent more serious mistakes (Hikmat, 2014). Controlling is the process of observing or monitoring the organization's implementation so that all work being carried out goes according to a predetermined plan.

The supervisory function is also defined as an assessment that is the task of every manager. For educational institutions, assessment is an important element in management activities. Because the assessment is related to efforts to improve the effectiveness and efficiency of the organization in achieving its goals. Assessing an activity, whether it was carried out well or failed, is the target of assessment or supervision. In the assessment, the value of a program, product, project, process, goal, or curriculum (Syafaruddin, 2005). In line with this, it can be emphasized that the assessment of education in a school or institution must be comprehensive and directed towards measuring the main goal of improving/enhancing students' learning experience.

Supervision is a basic process that is essentially still needed no matter how complex and broad an organization is (Fattah, 2001). The steps that can be taken in control are as follows: 1.) Determining the standard or standard size that will be the benchmark; 2.) Measurement or assessment of the activities that are actually carried out (or the results of those activities); 3.) Comparison between the implementation of the activities or their results with predetermined benchmarks to find out deviations or differences that occur; 4.) Correction of deviations or differences that occur so that all activities or results are in accordance with what has been determined (Gie, 1992). Control is defined as the process of monitoring, evaluating, and reporting the plans that have been set for corrective actions for further improvement. While the supervisor is only limited to giving advice, the controller will conduct the follow-up.

Supervision in educational organizations is directed at implementing the overall course and training institution program, the end of which is to improve the quality of learning. In this regard, the Career Busana course institution supervises the reporting of course program activities using a system that utilizes technology, such as monitoring student activities and learning outcomes through the WhatsApp group.

\section{CONCLUSION}

Management is an important thing in an organization or institution. Goals will be more easily achieved if management in an institution or organization can be carried out properly. Management also makes a program implementation process more structured and directed in the organization. Humans are the main element that greatly influences the process of management. The industrial revolution and society 5.0 is an unavoidable condition. The term arises due to sophisticated technology and continues to grow. The influence and consequences of this condition caused a revolution in all aspects of life, including education and training. Therefore, to determine the level of readiness of a course and training institution, it is necessary to develop a strategy in management.

POAC is a management function based on planning, organizing, actuating, and controlling. These four main functions of management are often used to determine the extent to which the management process is carried out so that through these four aspects it can be seen the level of readiness for the industrial revolution 4.0 and society 5.0. Based on the management function, the fashion training and course institution at Career Fashion are considered ready to face the industrial revolution 4.0 and society 5.0. This is based on the curriculum, which has been adapted to the needs of industry 4.0 and society 5.0, and the management and implementation of the learning process to the supervision or evaluation held that have integrated and utilized technology and information systems. 


\section{REFERENCES}

Afandi, M., Chamalah, E., \& Wardani, O. P. (2013). Model dan metode pembelajaran di sekolah. In Perpustakaan Nasional Katalog Dalam Terbitan (KDT) (Vol. 392, Issue 2). https://doi.org/10.1007/s00423-006-0143-4

Bell, S. (2010). Project-based learning for the 21 st century: Skills for the future. The Clearing House: A Journal of Educational Strategies, Issues and Ideas, 83(2), 39-43. https://doi.org/10.1080/00098650903505415

Fattah, N. (2001). Landasan manajemen pendidikan (1st ed.). Remaja Rosdakarya. http://perpus.tasikmalayakab.go.id/opac/detail-opac?id $=3422$

Gie, T. L. (1992). Administrasi perkantoran modern (4th ed.). Liberty. https://opac.perpusnas.go.id/DetailOpac.aspx?id=664536

Hermann, M., Pentek, T., \& Otto, B. (2016). Design principles for industrie 4.0 scenarios. 2016 49th Hawaii International Conference on System Sciences (HICSS), 3928-3937. https://doi.org/10.1109/HICSS.2016.488

Kementerian Ketenagakerjaan Republik Indonesia. (2019). Data angkatan kerja 35. Satudata.Kemnaker.Go.Id. https://satudata.kemnaker.go.id/data-angkatan-kerja

Mcgrath, S., \& Mulder, M. (2019). Handbook of Vocational Education and Training. In Handbook of Vocational Education and Training. https://doi.org/10.1007/978-3-319-94532-3

Meriza, I. (2018). Pengawasan (Controling) Dalam Institusi Pendidikan. At-Ta'dib: Jurnal Ilmiah Prodi Pendidikan Agama Islam, 10(1), 37-46. http://ejournal.staindirundeng.ac.id/index.php/tadib/article/view/113

Miles, M. B., \& Huberman, A. M. (2009). Qualitative data analysis: An expanded sourcebook (2nd ed.). Sage Publications. https://books.google.co.id/books?hl=id\&lr=\&id=U4lU_wJ5QEC\&oi $=$ fnd\&pg $=$ PA10\&dq $=$ Qualitative + data + analysis + Miles\&ots $=\mathrm{kFTH} 2 \mathrm{HVZ1T} \&$ sig=ctEW_Fy8_VcHJaSI16_m2hLHAKA\&redir_esc $=y \# v=$ onepage $\& \mathrm{q}=$ Qualitative data analysis Miles\&f=false

O'Hair, D., Friedrich, G. W., \& Dixon, L. D. (2009). Strategic communication in business and professions (6th ed.). Kencana Prenada Media Group.

Rizani, R. (2019). Implementasi privacy shield dalam menggunakan protection of personal data UNI Eropa - Amerika. Jurnal Ilmu Hubungan Internasional, 7(3), 1209-1218. https://ejournal.hi.fisip-unmul.ac.id/site/?p=3049

Salgues, B. (2018). Society 5.0: Industry of the future, technologies, methods and tools (1st ed.). ISTE Ltd and John Wiley \& Sons, Inc. https://books.google.co.id/books?hl=en\&lr=\&id=pO1qDwAAQBAJ\&oi=fnd\&pg=PP2\&dq $=$ Society $+5.0,+$ Industry + of + the + future,+ technologies,+ methods + and + tools\&ots $=0 \mathrm{H} 1 \mathrm{GTo}$ TE8V\&sig=I-zJdYeAGTvn6vO9Hj_S3qnJBDk\&redir_esc=y\#v=onepage\&q=Society $5.0 \% 2 \mathrm{C}$ Industry of the future $\% 2 \mathrm{C}$ technologies $\% 2 \mathrm{C}$ methods and tools $\& \mathrm{f}=$ false

Schwab, K. (2016). The fourth industrial revolution. Crown Business. https://books.google.co.id/books?hl=en\&lr=\&id=ST_FDAAAQBAJ\&oi=fnd\&pg=PR7\&d $\mathrm{q}=$ The + Fourth + Industrial+Revolution + Schwab, + Klaus\&ots=DUjz4WyzSP\&sig $=$ h1 gBSeC U8mtw9dqIM6k3ylZaOgU\&redir_esc $=\mathrm{y} \# \mathrm{v}=$ onepage $\& \mathrm{q}=$ The Fourth Industrial Revolution Schwab\%2C Klaus\&f=false

Singh, M. (2005). Meeting basic learning needs in the informal sector: Integrating education and training for decent work, empowerment, and citizenship. Springer. https://books.google.co.id/books?hl=en\&lr=\&id=enBkghBDTGMC\&oi=fnd\&pg=PR5\&dq $=$ Meeting + basic + learning + needs + in + the + informal + sector:+integrating + education + and + tra ining + for + decent + work, + empowerment + and + citizenship + Madhu + singh\&ots $=$ zpMM7L $7 f$ 
OK\&sig=AiXKRQhpWrsh6mYNPUgN6Psv_gE\&redir_esc=y\#v=onepage\&q=Meeting basic learning needs in the informal sector $\% 3 \mathrm{~A}$ integrating education and training for decent work $\% 2 \mathrm{C}$ empowerment and citizenship Madhu singh\& $\mathrm{f}=$ false

Sudira, P. (2018). Metodologi pembelajaran vokasional Abad XXI: Inovasi, teori, dan praksis. In B. Lastariwati (Ed.), UNY Press. UNY Press. http://staffnew.uny.ac.id/upload/131655274/penelitian/DOC C 4 Buku Referensi Metodologi Pembelajaran Vokasional Abad XXI Inovasi, Teori, dan Praksis.pdf

Sugiyono, S. (2013). Metode penelitian pendidikan: Pendekatan kuantitatif, kualitatif, dan $R \& D$ (17th ed.). Alfabeta.

Syafaruddin, S. (2005). Manajemen lembaga pendidikan Islam (1st ed.). Ciputat Press. http://repository.uinsu.ac.id/2895/1/Manajemen Lembaga Pendidikan Islam.pdf

Syamsi, I., Westra, P., \& Sutarto, S. (1982). Ensiklopedi administrasi. Gunung Agung. https://opac.perpusnas.go.id/DetailOpac.aspx?id=658343

Terry, G. R. (1977). Principles of management. IRWIN. https://lib.ui.ac.id/detail.jsp?id=20121801

Thach, E. C., \& Murphy, K. L. (1995). Competencies for distance education professionals. Educational Technology Research and Development, 43(1), 57-79. https://doi.org/10.1007/BF02300482

Wijaya, C., \& Rifa'i, M. (2016). Dasar-dasar manajemen: Mengoptimalkan pengelolaan organisasi secara efektif dan efisien. Perdana Publishing. http://repository.uinsu.ac.id/2895/1/Manajemen Lembaga Pendidikan Islam.pdf

Winanti, W., Gaol, F. L., Napitupulu, T. A., Soeparno, H., \& Trisetyarso, A. (2019). Learning framework in the industrial age 4.0 in higher education. 2018 Indonesian Association for Pattern Recognition International Conference (INAPR), 1, 227-232. https://doi.org/10.1109/INAPR.2018.8627039

Zainal, V. R., Ramly, H. M., Mutis, T., \& Arafah, W. (2014). Manajemen sumber daya manusia untuk perusahaan dari teori ke praktik. RajaGrafindo Persada. http://perpustakaan.bppsdmk.kemkes.go.id//index.php?p=show_detail\&id=3246 